Studia Rossica Gedanensia, 6/2019, 223-230, ISSN 2392-3644 (online), ISSN 2449-6715 (print) DOI: https://doi.org/10.26881/srg.2019.6.18

\title{
ОСНОВНЫЕ ФОРМЫ РЕАЛИЗАЦИИ \\ КОНСТРУКТИВНОЙ ГРАЖДАНСКОЙ АКТИВНОСТИ МОЛОДЕЖИ БЕЛАРУСИ
}

\author{
ОЛЬГА СТАШКЕВИЧ \\ Национальная академия наук Беларуси \\ Институт философии \\ Центр социально-философских и антропологических исследований \\ ул. Сурганова 1/2, 220072, г. Минск, Беларусь \\ e-mail: stashkevich.olha@rambler.ru \\ ORCID: https://orcid.org/0000-0002-9918-0093 \\ (получено 27.09.2019; принято 6.10.2019)
}

\section{Abstract \\ The Main Forms of Constructive Civic Engagement Among Young People in Belarus}

The paper describes the main forms of civic engagement of the individual: organizational, constant, situational, protesting, etc. The author concludes that it is necessary to develop a greater number of networked self-governing youth initiatives which will help to strengthen civil society in Belarus in the future.

Key words: civil activity of the individual, youth initiative, youth organizations

\section{Резюме}

В статье рассмотрены основные формы реализации гражданской активности личности: организованные, постоянно функционирующие, ситуативные, протестные и др. Сделан вывод о необходимости развития в большей мере сетевых 
самоуправляемых молодежных инициатив, что будет в дальнейшем способствовать укреплению гражданского общества в Беларуси.

Ключевые слова: гражданская активность личности, молодежные инициативы, молодежные организации

Гражданское общество в Республике Беларусь находится на пути своего становления. «Оно невелико по числу людей и организаций, готовых проявлять свою гражданскую позицию и активно влиять на темпы и направление развития общества», - отмечается на сайте Международного консорциума Евробеларусь (Гражданское общество, online), и с этим нельзя не согласиться. Но все же в нашей стране созданы необходимые условия для формирования и развития гражданских инициатив, проявления гражданской активности, в том числе и в молодежной среде. Гражданская активность личности проявляется посредством готовности человека вносить вклад во все сферы развития социума, в реализацию общественно-значимых интересов, обращения внимания общественных и властных структур к разнообразным общественным проблемам, добросовестного исполнения гражданских прав и обязанностей.

Разнообразие форм конструктивной гражданской активности молодежи зависит от развития общественных институтов (политического, экономического, правового и др.), предоставляющих молодежи разнообразные возможности для участия в жизни страны. Проявление гражданской активности имеет различную степень институализации: начиная от стихийно образованной группы (к примеру, самоорганизовавшаяся группа участников митинга или протеста) до высокоорганизованной, постоянно функционирующей общности людей (например, политическая партия, общественная организация). Разнообразие форм гражданской активности молодежи чрезвычайно широко. В Беларуси она представлена в следующих формах:

\section{1. Организованные формы гражданской активности молодежи}

В первую очередь это разнообразные молодежные объединения, деятельность которых строится на стремлении самой молодежи объединиться на основе собственных интересов и ценностей, а также добровольного членства. Часто создание молодежных организаций инициируется различными социальными группами (к примеру, властными структурами) с целью воспитания, социализации и контроля молодежи.

В Беларуси зарегистрировано около 300 молодежных организаций (Список, online). Флагманами являются те объединения, которые созданы при непосредственной поддержке государственных органов: Общественное объединение «Белорусский республиканский союз молодежи» (БРСМ), которое объединяет вокруг себя подростков и молодежь в возрасте от 14 до 31 года, имеет тесные связи (и «прямой лифт») с рядом других общественных объединений Беларуси 
(к примеру, с Республиканским объединением «Белая Русь»); Республиканская молодежная общественная организация «Лига добровольного труда молодежи»; Республиканское общественное объединение «Белорусская Ассоциация клубов ЮНЕСКО»; Лига интеллектуальных команд.

В неменьшей степени объединяющую роль играют организации, созданные при поддержке иных социальных институтов (например, религиозных конфессий - «Белорусская ассоциация молодых христианских женщин», «Союз православной молодежи имени Святого Георгия Победоносца») или организованные для решения узких социальных проблем («Анонимные наркоманы», «Белорусская ассоциация помощи детям-инвалидам и молодым инвалидам»); для реализации профессиональных интересов («Белорусская ассоциация студентов-архитекторов», «Белорусское общество молодых неврологов и нейрохирургов») и политических устремлений («Белорусская молодежная палата», «Гражданский форум»); для проведения досуга и хобби («Белорусская рок-лига»), защиты живой природы и окружающей среды («Зеленый дуб», «Ради жизни на земле»); для защиты семьи и детства («В защиту жизни и семейных ценностей», «Даун Синдром»); а также военно-патриотические организации («Военно-патриотический клуб «Поиск»», «Рыцари Великого Княжества») и др.

\section{2. Самоорганизованные (инициативные) формы гражданской активности}

Гражданская активность личности может формироваться стихийно, в стороне от различных общественных институтов (государственных учреждений, политических организаций и т.п.). К формам самоорганизованной гражданской активности можно отнести разнообразные общественные комитеты, союзы, движения, инициативные группы и т.п., которые возникают спонтанно; зачастую их создают в преддверии каких-либо масштабных событий или для решения каких-либо одномоментных вопросов. Их деятельность достаточно разнообразна - это и сбор подписей, и подача петиций, и организация уличных манифестаций, пикетов, и распространение печатной продукции. «Такая гражданская активность, как правило, давит на органы власти (...) в целях принятия политических решений, угодных протестующим» (Фролов 2015). И не только политических, но и экономических, социальных решений.

Здесь существует большая вероятность, что конструктивная гражданская активность может перейти в деструктивную (мирные акции могут закончиться погромами и акциями неповиновения), а также, что за мирными и социально значимыми лозунгами может скрываться иная цель, например, изменение политической ситуации в корыстных целях отдельных граждан или групп граждан и т.п. 


\section{3. Институциональные и неинституциональные формы гражданской активности}

Институциональные формы гражданской активности молодежи связаны с использованием определенных институций, таких как общественные и политические объединения, партии, профсоюзы и др.

Неинституциональные формы не имеют четких публичных проявлений, но в то же время объединяют в себе весомую долю гражданской активности и выражаются в следующих видах:

- непредвиденная гражданская активность заключается в проявлении неподотчетной, недекларированной, ненавязанной гражданской позиции. Она может выражаться в различных акциях протеста. Ярким примером такой активности служат «Марши нетунеядцев», которые объединили большое количество населения страны против Декрета № 3 «О предупреждении социального иждивенчества». Иллюстрацией непредвиденной гражданской активности в молодежной среде служат «Революция через социальную сеть» (акции «молчаливого» протеста) (2011 г.), вызванные девальвацией белорусского рубля и ухудшением качества жизни; студенческая акция «Марш любви и солидарности» (2015 г.), направленная на отмену платных пересдач, и т.п. (Круглов 2014b).

- анонимная гражданская активность молодежи представляет собой латентную форму участия в общественной жизни страны. В связи с развитием информационных технологий, возможностью как офлайн (посредством написания анонимных жалоб в различные организации и властные структуры), так и онлайн (проявлять свою гражданскую активность в сети Интернет, скрываясь под вымышленными никами) решать общественные и личные проблемы, не раскрывая свою личность перед широкой аудиторией. Такая активность часто связана с иждивенческой формой гражданской активности. Ее суть заключается в перекладывании решения социально-политических проблем на других. Обычно она выражается в формах обращения в органы местного или государственного самоуправления и власти с коллективными или индивидуальными предложениями, жалобами, прошениями и т.п. (Круглов 2014а: 59).

- информационно-коммуникационная форма гражданской активности выражается через возможность коммуникации с властными и общественными структурам онлайн (через электронные приемные, электронные формы обращения граждан, интернет-площадки). К примеру, в белорусском интернетпространстве существует площадка Change.org, на которой любой желающий может написать свою петицию или присоединиться к чужой инициативе (Глобальная платформа, online). При этом петиция может быть направлена на решение совершенно разных общественных проблем: от спасения болот от уничтожения до создания качественной белорусской версии Google. К тому же данный ресурс на самом деле позволяет решить некоторые назревшие проблемы.

Следует отметить, что неформальная гражданская активность молодежи повышается и растет число ее неинституциональных форм, поэтому государство 
должно регулировать этот рост посредством инициации различных проектов, направленных на создание системы социального партнерства общества и власти.

\section{4. Сетевая и иерархическая форма гражданской активности молодежи}

Молодежные организации, общности и солидарности могут организовываться и управляться посредством вертикальной или горизонтальной структуры, другими словами, могут иметь иерархическую (пронизанную жесткими вертикальными связями и отношениями) или сетевую (в которой все члены равны в своих правах, обязанностях и ответственности) формы. По иерархическому принципу организована работа республиканских общественных объединений, профессиональных союзов и студенческого самоуправления.

Конечно, организации, которые поддерживаются органами власти, имеют больше возможностей плодотворного развития и оказания положительного воздействия на юношество и молодежь посредством воспитания гражданской и политической культуры, патриотизма, просвещения в области прав человека и достоинства личности. Членство в данных организаций также имеет ряд преимуществ: некоторые льготы (например, членский билет БРСМ дает право на получение скидок в ряде заведений страны); большую возможность принимать участие в различных мероприятиях, конкурсах, грантах (к примеру, в мероприятиях, организуемых ФПБ, могут участвовать только члены профсоюзов).

Однако при вертикальном управлении молодежными организациями существует и ряд недостатков. Проиллюстрируем это на примере организации студенческого самоуправления (которое априори направлено на формирование таких личностных качеств, как активность и ответственность). В каждом вузе страны создана система студенческого самоуправления, но его деятельность координируется управлениями воспитательной работы с молодежью, деканами факультетов, первичными объединениями БРСМ, что демонстрирует подчиненность вышестоящим органам.

С одной стороны, студенческие инициативы в вузах приветствуются и поддерживаются, но, с другой стороны, практически не остается возможности для проявления низовой активности, так как на все ключевые позиции ответственные (лидеры) назначаются (к примеру, старосты студенческих групп не избираются учебным коллективом, а назначаются деканами из числа лучших студентов). Но ведь самоуправление и заключается в предоставлении права каждому самостоятельно принимать и реализовывать решения в рамках своей компетентности.

Говоря о сетевой гражданской активности, исследователи выделяют три типа организации гражданской активности: сетевая, протовертикальная, гибридная (Головин, Фролов 2016; Соколов, Маклашин 2013).

Большой интерес представляет сетевая форма проявления гражданской активности молодежи. В развитии данной формы значительную роль играют со- 
временные интернет-технологии. Существующие интернет-ресурсы дают возможность быстро и дешево найти соратников для решения различных задач.

Социальные сети, гражданские приложения, краудсорсинговые и краудфандинговые площадки представляют значительные возможности для коммуникации, передачи информации, поиска ресурсов. Они становятся реально действующим инструментом горизонтальных отношений в обществе (Фролов 2015: 27).

Такая форма организации молодежных инициатив присуща в основном некоммерческому сектору, незарегистрированным объединениям. Главными характеристиками, по мнению А.В. Соколова и И.С. Маклашина, сетевого гражданского общества являются «открытость», т.е. «установление широких многомерных связей коммуникации» и «спонтанность» - «свободное формирование, текучесть, постоянное изменение структуры» (Соколов, Маклашин 2013: 159). Сетевая гражданская активность строится на принципах равенства, добровольности участия, а также отсутствия иерархического управления и ресурсного взаимодействия.

Иллюстрацией низовой гражданской активности служат кампании в защиту среды проживания (Кампания местных жителей в защиту Восточного сквера, апрель 2017 года), в защиту языкового равноправия (акции, проводимые «Таварыствам беларускай мовы»), против разрушения исторических памятников (Гуманитарно-просветительское общественное объединение "Садружнасць Палесся”), различные социальные инициативы («Еда вместо бомб» / Food not bombs). Следует обратить внимание на то, что сетевые инициативы оказывают позитивное влияние на решение общественных местных проблем.

Несмотря на то, что сетевая организация гражданской активности молодежи изначально была низовой, теперь ее активно стали использовать и властные структуры, внедряя «данную форму организации в собственные технологии управления общественно-политическим процессом» (Фролов 2015).

Протовертикальная сетевая гражданская активность представляет собой движения, «созданные властными структурами для актуализации вопросов по определенным темам» (Фролов 2015). Такие организации могут создать разветвленную сеть региональных представительств, задействовать административный ресурс. В качестве примера можно привести развитие истории со строительством бизнес-центра в урочище Куропаты, когда властные структуры согласились с активистами, что строительство бизнес-центра недопустимо, что необходимо создать мемориал и благоустроить Куропаты. Был объявлен всенародный сбор средств на благоустройство; министерство культуры объявило конкурс на эскиз памятного знака (мемориала) Куропаты (В Минкультуры, online). К наведению порядка в урочище присоединились профсоюзы, «Белая Русь», БРСМ, министерство культуры, организовав 25 марта 2017 года субботник (Если мы не помним, online). Главным недостатком протовертикальной гражданской активности является то, что подобные сетевые организации получают должное развитие только при наличии поддержки со стороны органов власти, без внешнего контроля сетевое движение затухает. 
Гибридная сетевая активность - новое явление для Беларуси - представляет собой смешанную структуру. Как правило, лидеры движения имеют связь с органами власти, получают от них поддержку, но, с другой стороны, это и низовая активность граждан, принимающих участие в деятельности движения на добровольных началах.

Ярким примером тому служит поисково-спасательный отряд «Ангел», который оказывает помощь в поиске пропавших людей, а также занимается профилактикой пропажи детей и безвестного исчезновения взрослых. Лидеры отряда тесно сотрудничают с МВД. Последнее задействует поисковые отряды для установления свидетелей и местонахождения пропавших. Организация также проводит республиканские учения для добровольцев по поиску заблудившихся людей в лесу (Поисково-спасательный отряд, online). Как отмечал Х. Хекхаузен: «Жизнь любого человека представляет собой непрерывный поток активности (...). Формы активности варьируются от образов-представлений, проходящих перед нашим внутренним взором в снах и грезах, до действий, произвольно осуществляемых нами по заранее намеченному плану» (Хекхаузен 1986: 12).

Подводя итоги, отметим, что разнообразие форм и видов гражданской активности должно способствовать формированию у белорусской молодежи потребности в самоопределении и рефлексии, личной и коллективной ответственности, повысить уровень ее нравственной и эстетической культуры, приобщить к духовным ценностям и традициям нашего народа, обеспечить участие в общественной жизни, помочь ей приобрести опыт взаимодействия с государственными органами власти в реализации своих прав и интересов, в разрешении наиболее актуальных молодежных проблем. Развитость гражданской активности - важнейший показатель укрепления позиций гражданского общества в нашей стране, и проявление небезразличного отношения к целям, ценностям и идеалам демократии.

\section{Библиография}

«Esli my ne pomnim istoriû, ona povtorâetsâ». Kak v Den' Voli kommunisty i BRSM ubirali Kuropaty (2017). (Online) https://news.tut.by/society/536810.html/ (dostup 21.11.2017) [«Если мы не помним историю, она повторяется». Как в День Воли коммунисты и БРСМ убирали Куроnaты (2017). (Online) https://news.tut.by/society/536810.html/ (доступ 21.11.2017)].

Frolov, A.A. (2015). Setevye formy organizacii graždanskoj aktivnosti v sovremennoj Rossii. Avtoreferat dissertacii na soiskanie učenoj stepeni kandidata političeskih nauk. Âroslavl' Âroslavskij gosudarstvennyj universitet im. P.G. Demidova [Фролов, А.А. (2015). Сетевые формы организации гражданской активности в современной России. Автореферат диссертации на соискание ученой степени кандидата политических наук. Ярославль: Ярославский государственный университет им. П.Г. Демидова].

Global'naâ platforma dlâ vaših kampanij (2019). (Online) https://www.change.org (dostup 21.09.2019) [Глобальная платформа для ваших кампаний (2019). (Online) https://www.change.org (доступ 21.09.2019)].

Golovin, U.A., Frolov, A.A. (2016). Praktiki setevoj graždanskoj aktivnosti v sovremennoj Rossii. Gosudarstvennoe i municipalnoe upravlenie. Učenye zapiski SKAGS, 2: 195-198 [Головин, Ю.А., 
Фролов, А.А. (2016). Практики сетевой гражданской активности в современной России. Государственное и муниципальное управление. Ученые записки СКАГС, 2: 195-198].

Graždanskoe obŝestvo (2019). (Online) https://eurobelarus.info/civil-society/ (dostup 21.09.2019) [Гражданское общество (2019). (Online) https://eurobelarus.info/civil-society/. (доступ 21.09.2019)].

Hekhauzen, X. (1986). Motivaciâ $i$ deâtel'nost': $v$ dvuch tomach. T. 2. Moskva: Pedagogika [Хекхаузен, Х. (1986). Мотивация и деятельность: в двух томах. Т. 2. Москва: Педагогика].

Kruglov, M.S. (2014a). Sovremennye formy graždanskoj aktivnosti v političeskom processe Rossijskoj Federacii. Teoriâ i praktika obŝestvennogo razvitiâ, 3: 57-65 [Круглов, М.С. (2014). Современные формы гражданской активности в политическом процессе Российской Федерации. Теория и практика общественного развития, 3: 57-65].

Kruglov, N.S. (2014b). Sovremennye formy graždanskoj aktivnosti v političeskom processe Rossijskoj Federacii. Avtoreferat dissertacii na soiskanie stepeni kandidata političeskih nauk. Moskva: Istoriko-arhivnyj institut federal'nogo gosudarstvennogo bûdžetnogo obrazovatel'nogo učreždeniâ «Rossijskij gosudarstvennyj gumanitarnyj universitet» [Круглов, Н.С. (2014). Современные формы гражданской активности в политическом проиессе Российской Федерации. Автореферат диссертации на соискание степени кандидата политических наук. Москва: Историко-архивный институт федерального государственного бюджетного образовательного учреждения «Российский государственный гуманитарный университет»].

Poiskovo-spasatel'nyj otrâd "Angel» (Search and Rescue squad "Angel") (2019). (Online) http://angelsearch.by/node/41/ (dostup 21.07.2019) [Поисково-спасательный отряд «Ангел» (Search and Rescue squad "Angel") (2019). (Online) http://angel-search.by/node/41/ (доступ 21.07.2019)].

Sokolov, A.V. Maklašin, I.S. (2013). Setevaâ graždanskaâ aktivnost’ v sovremennoj Rossii. Vestnik Kostromskogo gosudarstvennogo universiteta, 6: 159-161 [Соколов, А.В. Маклашин, И.С. (2013). Сетевая гражданская активность в современной России. Вестник Костромского государственного университета, 6: 159-161].

Spisok zaregistrirovannyh molodežnyh organizacij. (Online) http://oeec.by/wp-content/ uploads/2016/01.pdf. (dostup 21.09.2019) [Список зарегистрированных молодежных организащий (2019). (Online) http://oeec.by/wp-content/uploads/2016/01.pdf. (доступ 21.09.2019)].

$V$ Minkul'tury postupili pervye zaâvki na konkurs èskiznyh proektov pamâtnogo znaka «Kuropaty» (2017). (Online) http://www.belta.by/culture/view/v-minkultury-postupili-pervye-zajavki-nakonkurs-eskiznyh-proektov-pamjatnogo-znaka-kuropaty-242509-2017/ (dostup 21.11.2017) [В Минкультуры поступили первые заявки на конкурс эскизных проектов памятного знака «Kуропаты» (2017). (Online) http://www.belta.by/culture/view/v-minkultury-postupilipervye-zajavki-na-konkurs-eskiznyh-proektov-pamjatnogo-znaka-kuropaty-242509-2017/ (доступ 21.11.2017)]. 